\title{
単錨泊船の振れ回り運動中に生じる錨鎖張力の 緩和に関する研究一II.
} 一バウスラスターを利用した錨鎖張力の緩和一

井.上 欣 三*

An Investigation on Reducing Cable Tension Caused by Swing Motion of a Ship Moored at Single Anchor in Wind-II - On Reducing Cable Tension by Application of Bow Thruster-

Kinzo INOUUE

\begin{abstract}
The author tried to evaluate by means of simulation that to what degree cable tension can reduce through the effect of bow thruster which was operated so as to lessen the difference of the angle between the direction of the wind and the ship's head. The results of the simulation showed that not only cable tension but also the extent of swing motion reduced significantly by application of bow thruster, and gave us some instructions regarding the operation of bow thruster as follows;

(1) The degree of the effect is not concerned in the starting point of operation of bow thruster.

(2) It is not desirable to do so sensitive control for the small difference of the angle between the direction of the wind and the ship's head.

(3) In the present condition, it is suitable to permit the steady swing motion to some extent, in this sense, the adequate magnitude of the thrust of bow thruster seems to be $60 \sim 80 \%$ of the frontal wind pressure of the ship.

(4) Then, it is expected that the magnitude of cable tension decreases by about $40 \%$, and the extent of swing motion decreases by $35 \%$ at least.

\section{1. はじめに}

第 1 報(1)に特いては，錨泊船の振れ回り運動中に生じる錯鎖張力の大きさは主として船体重心の横移動速度と 船首回頭角速度の大きさに依存することを示すとともに，安全な錨泊を確保するにはこれらの要因に対して適切 なコントロールを行ら必要があることを指摘した。

錨泊時の安全対策としての秋水の増加やトりムの調整は，風抵抗の減少・水抵抗の増加という手段によって振 れ回り運動速度の軽減を計ったものであると解釈できるが，受風面積が大きい上に契水やトリムの調整のむつか しい自動車専用船やカーフェリーなど，一般に錨泊に弱いと言われている船舶に対してはさらに積極的に振れ回 り運動速度をコントロールする必要があるらと思われる。

そこで，ここでは，バウスラスターが発生する横力と回頭モーメントを利用して船体の横移動速度と船首回頭 角速度を減衰させることを試み，これが振れ回りの抑制拉よび錨鎖張力の緩和にどの程度効果的であるかをシミ ニレーションにより俨価した。
\end{abstract}

\section{2. 単錨泊振れ回り運動のシミュレーション}

2. 1 座標系拈よび運動方程式

風の中で単錯泊する船の振れ回り運動を図 1に示す座標系を用いて表わすことにする。

* 正会員 神严商船大学（神戸市東灘区深江南町 5丁目 1-1） 


$$
\begin{array}{ll}
\text { ここに, } & \\
0-X Y & \text { 錨位置を原点とする静止空間座標 } \\
G-x y & \text { 船体重心を原点とする船体固定座標 } \\
\phi & \text { 船首尾線とY軸のなす角 (船首角) } \\
\theta & \text { 錨鎖と } Y \text { 軸のなす角 (錨鎖角) }
\end{array}
$$

である。風は $Y$ 軸に沿って図の上方から下方に向かって吹くものとする。ま た，船体運動は平面運動に限定して取り扱い，次式に示す操緃性の運動方程 式を用いて表わすことにする。

$$
\begin{aligned}
& \left(m+m_{x}\right) \dot{U}-\left(m+m_{y}\right) V R=F_{x w}+F_{x c} \ldots \ldots \ldots \ldots \ldots \ldots \\
& \left(m+m_{y}\right) \dot{V}+\left(m+m_{x}\right) U R=F_{y w}+F_{y c}+F_{y H}+\left(F_{y B}\right) \\
& \left(I_{z z}+J_{z z}\right) \dot{R}=M_{G W}+M_{G C}+M_{G H}+\left(M_{G B}\right) \ldots \ldots \ldots \ldots \ldots
\end{aligned}
$$

(1)，(2)，(3)式中の $U ， V ， R$ は重心を原点とする船体固定座標に和ける船

図 1 座 標 系 首尾方向，正横方向，回転方向の速度成分であり， $F_{x} ， F_{y}$ はそれぞれ $x$ 軸 方向， $y$ 軸方向の外力を， $M_{G}$ は重心回りの外力モーメントを表わしている。

\begin{tabular}{|c|c|c|}
\hline \multicolumn{2}{|c|}{ 項 } & 実 船 值 \\
\hline $\begin{array}{l}\text { 船本 } \\
\text { 竟要 }\end{array}$ & $\begin{array}{ll}\text { 総トン数 } & (G T) \\
\text { 全 長 } & \left(L_{o a}\right) \\
\text { 垂線間長 } & \left(L_{p p}\right) \\
\text { 幅 } & (B) \\
\text { 深 さ } & (D)\end{array}$ & $\begin{array}{r}16,109.32 \mathrm{ton} \\
224.98 \mathrm{~m} \\
210.00 \mathrm{~m} \\
32.20 \mathrm{~m} \\
27.60 \mathrm{~m}\end{array}$ \\
\hline 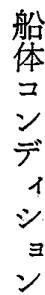 & 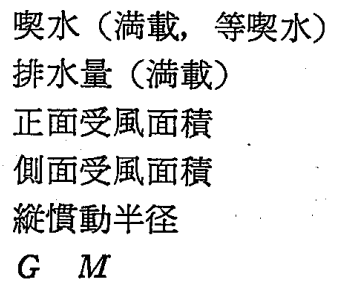 & $\begin{array}{r}9.33 \mathrm{~m} \\
32,889.00 \text { ton } \\
855.89 \mathrm{~m}^{2} \\
5,051.99 \mathrm{~m}^{2} \\
0.3 L_{p p} \\
0.03 B\end{array}$ \\
\hline
\end{tabular}
ここで, 右辺外力項には風圧力 (添字Wの項), 錨鎖反力 (添字 $C$ の項), 船体の流体力 (添字 $H$ の項) を考慮し, さらに，バウスラスターを作動する場合は添字 Bの項を付加する。

計算はすべて実船值を用い，時間刻みを 1 秒としてオイラー法により数值積分を行ったが，シミニレーション 実施にあたって設けた基本的な仮定は次のと和りである。

(1)風向，風速は一定とし，風圧力係数は辻氏(2)らの模型実験結果を用い，風圧力係数の相対風向角による変化 は sin, $\cos$ 関数で近似できるものとする。

表 1 モデル船の主要目捛よび計算条件
(2)錨鎖と海底との摩擦および錨鎖に働く流体力は無視 し, . 錨鎖は常に同一鉛直面上にあるるのとする。

(3)錨鎖反力は錨鎖の船体側取付点と錨位置との幾何学 的関係を用いてカテナリー理論に基づいて計算する。

(4)本船はプロペラの回転および操舵は行わない。ま た，船体に㗢く流体力のらち前後方向の力は小さいとし て無視する。

(5)流体力に関する諸係数は第 2 回操綎性シンポジウム

\begin{tabular}{|c|c|c|}
\hline 項 & 規 & 考 \\
\hline 錨の重量 & 10 ton & \\
\hline 錨鎖の径： & $76 \mathrm{~mm}$ & \\
\hline 錨鎖の単位重量 & $126.5 \mathrm{~kg} / \mathrm{m}$ & \\
\hline 錨鎖の破断試験荷重 & 306. 65ton & 第 2 種錨鎖 JIS 規格 \\
\hline 錨鎖の耐力試験荷重 & 219. 05ton & \\
\hline
\end{tabular}
テキスト(3)に示される方法にしたがって求める。

(6)シミュレーション開始時の船体初期位置は船体に働 く外力と錨鎖反力が釣り合う点とし，初期位置に拈いて 船首角 $10^{\circ}$ の初期偏角を与兄るが，1800秒間は空計算さ せ，その直後からの1時間を単位としてアウトプットさ せる。

表 2 錨および錨鎖の要目

\section{2 計算結果}

シミュレーションのモデルとした船は第 1 報での模型実験に供試船として用いた自動車專用船であり，計算に あたって設定した船体コンディション，錨，錨鎖の条件は表 $1 ; “$ 表 2 のと牤りである。計算はまず，バウスラス 


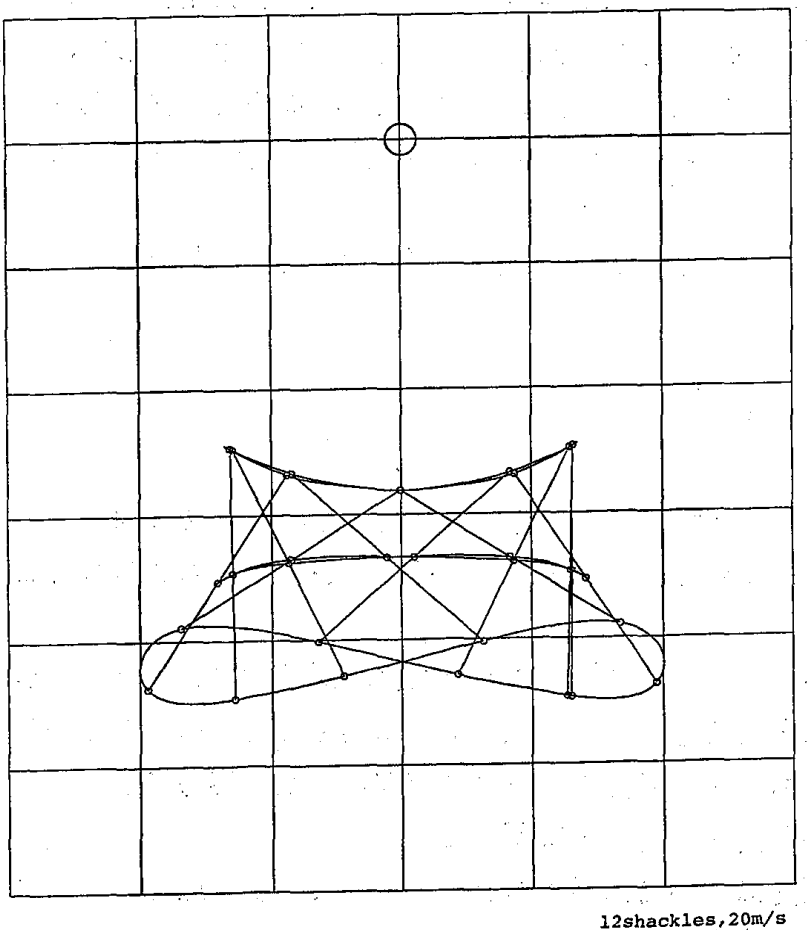

図 2 振れ回り運動の軌跡

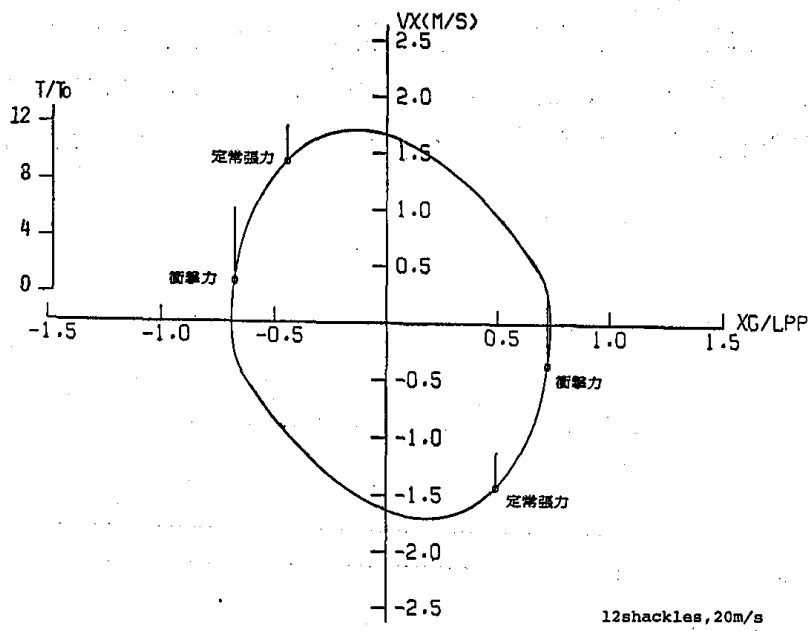

図 4 船体重心の横移動量と横移動速度の関係 ターを使用しない状態で，錨鎖伸出長 12 節，風速 $15 \mathrm{~m} / \mathrm{s}, 20 \mathrm{~m} / \mathrm{s}, 30 \mathrm{~m} / \mathrm{s}$ について行った。一例として風速 20 $\mathrm{m} / \mathrm{s}$ の場合の結果を囝 2 図 5 に示す。

図 2 は振れ回り 1 周期中の船首, 船尾, 重心の軌跡をプロットしたもので, 1 分ごとの船体姿勢も併せて示し ている。なお，図のますめの一辺は $0.5 L_{p p}$ に相当する。図 3 は振れ回り運動中の各要素の時間変化の様子を錨 鎖張力の変動とともにシミュレーションタイム 1 時間について示している。また，図 4 , 図 5 は重心の横移動量 と横移動速度および重心の横移動量と船首回頭角速度の関係を位相図で表わして括り，図には衝撃力および定常 張力の発生時機をその大きさとともにプロットしている。

一連の計算結果は図 2 にみられるように重心の振れ回り軌跡が多少偏平になることや，定量的な面において錨 鎖張力や運動速度に関連する要素の絶対值が約 2 倍程度過大に見積もられることなど，模型実験結果との対応に 
おいて完全な一致は得られなかった。これは錨鎖反力の計算をカテナリ一理論によったこと(4), 流体力係数や風 圧力係数を他の類似船型から推定したことなどに起因するるのと考えられ，今後改善してゆかなければならない が，その他の定性的な面に执いては模型実験結果の特徽をよく表わしているといえる。

殊に，船体が一旦風に立った後，急激な船首回頭に加えて船体が風下に扣とされ，錨鎖と船首尾線が注注一線 になる付近で衝撃力が発生し，このとき，船首回頭角速度が最大となる様子や，定常張力の発生に関して，錨鎖 角が $0^{\circ}$ となる付近から船体重心が $Y$ 軸を横切る付近にかけて横移動速度が最大となり，このとき縦移動速度拉 よび船首回頭角速度がほとんど０となる様子など，今後のシミュレーションに和いて重要と思われる点について はほぼ満足できる程度に再現されている。

ここに求めた計算結果は, 今後, バウスラスターの効果を評価するための基準值として用い, 効果の程度はこ の計算結果を基準とした比率で表わすことにする。

\section{3. バウスラスターによる船首角制御}

3. 1 シミュレーションの方法

バウスラスターは重心の前方 $0.41 L_{p p}$ の所に装備され, 作動直後から時間遅れなく左右とも同じ大きさの一 定推力が持続するもの゙と仮定する。また，バウスラスターの発停は今のところ航海士の手動操作によることを前 提とする。

バウスラスターの on-off 動作を人間の手を経ず自動的に行うシステムに叔いては, 制御対象を船体の横移動 速度, 船首回頭角速度，または，船首角とこれらの組み合わせといった複雑なるのに選んでも機構的に処理し得 るであろらが，ここでは，現状の船で航海士がバゥスラスターの発停時機や推力方向の決定を容易に察知し，判 断できる対象として風向と船首方位の偏角，つまり，船首角を制御対象に選んだ。

また，風軸を中心に左右それぞれ一定の船首角の範囲内に就いてはバウスラスターによる制御操作は行わない ものとする。このような一定の船首角の範囲をここでは不感帯と呼ぶことにする。

すなわち，本シミュレーションは風向と船首方位の間に一定以上のずれが生じたとき，そのずれを解消する方 向にバウスラスターを作動させ，できるだけ船首を風に立てるようにしようとするすのである。

この方法によるシミュレーション結果の一例を図 6〜図 9 に示す。計算条件は錨鎖伸出長 12 節, 風速 $20 \mathrm{~m} / \mathrm{s}$, バウスラスター推力 15 ton (正面風圧の 0.61 倍), 不感帯士 $10^{\circ}$ であり，計算にあたっては，まずバウスラスタ 一を使用しない状態で 1 周期振れ回らせ, その後, 船体重心が最も左に振れ切った時点でバウスラスターによる

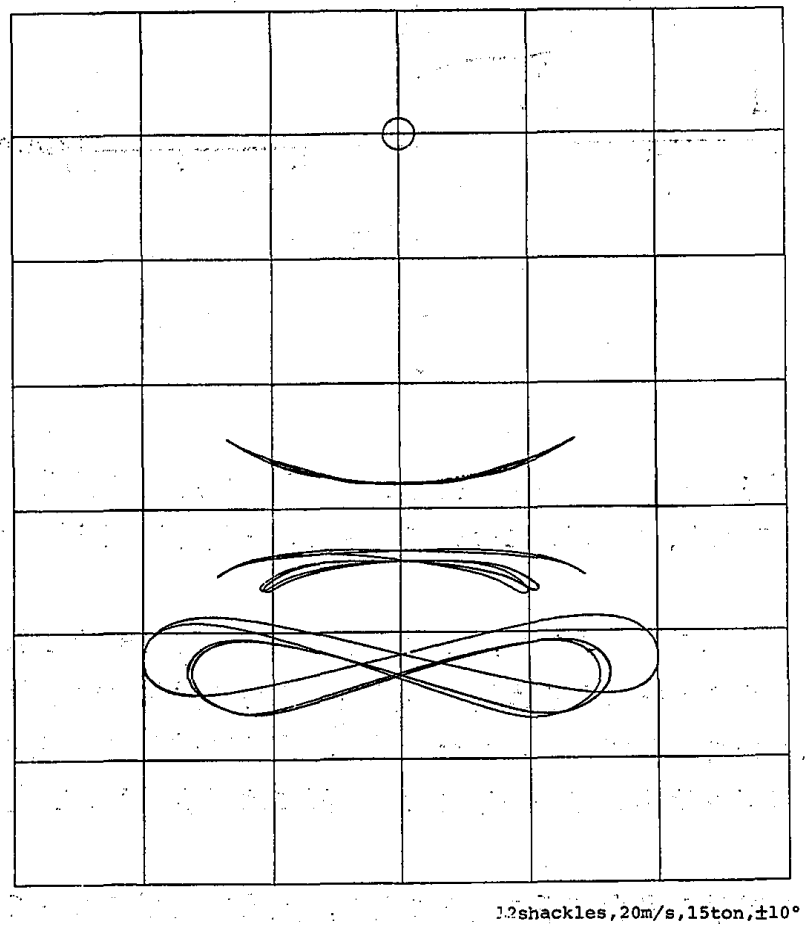

図6 バゥスラスター作動後の振れ回り運動軌跡
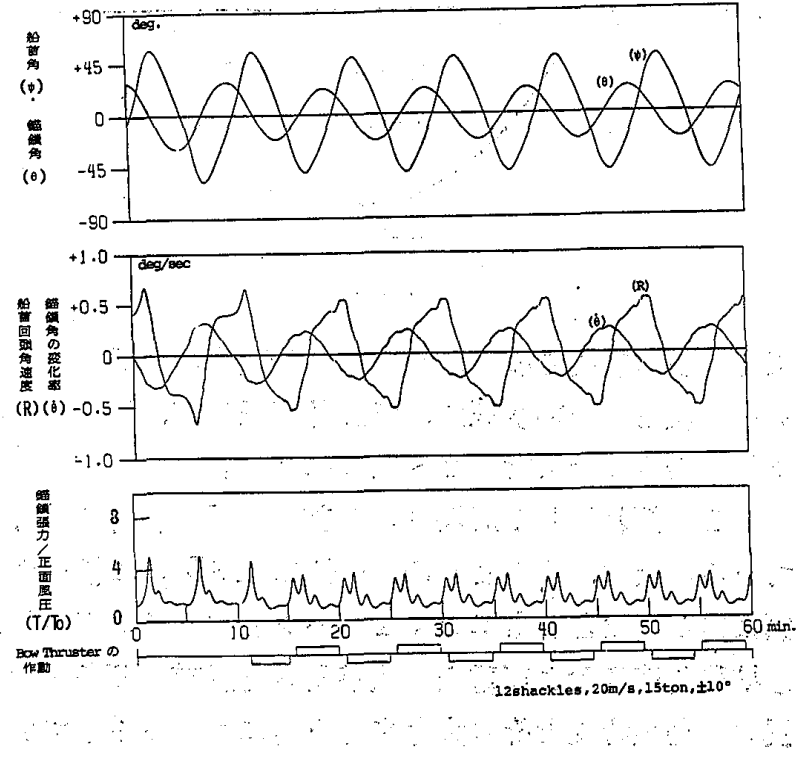

図 7 ・゙ウスラスター作動後に打ける各要素の時間変化 


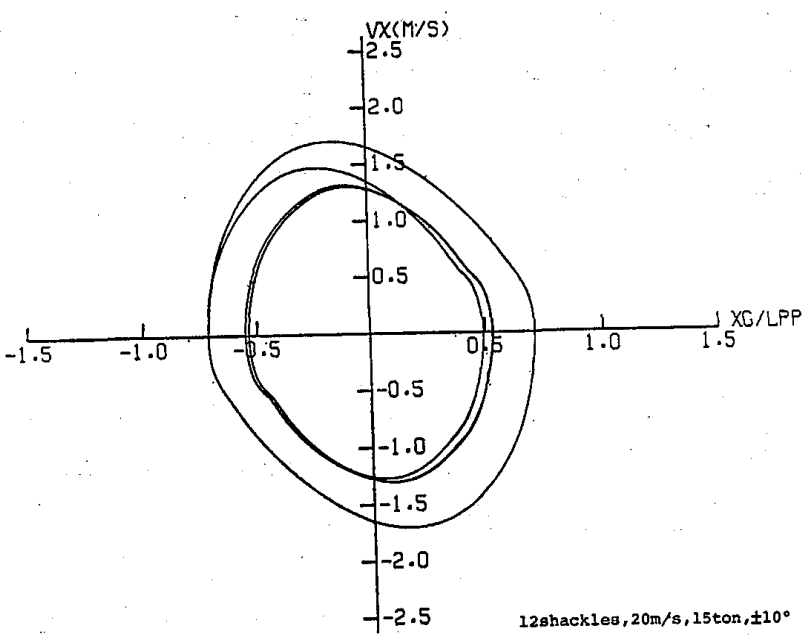

図 8 バウスラスター作動後にお预子る船体重心の 横移動量と横移動速度の関係

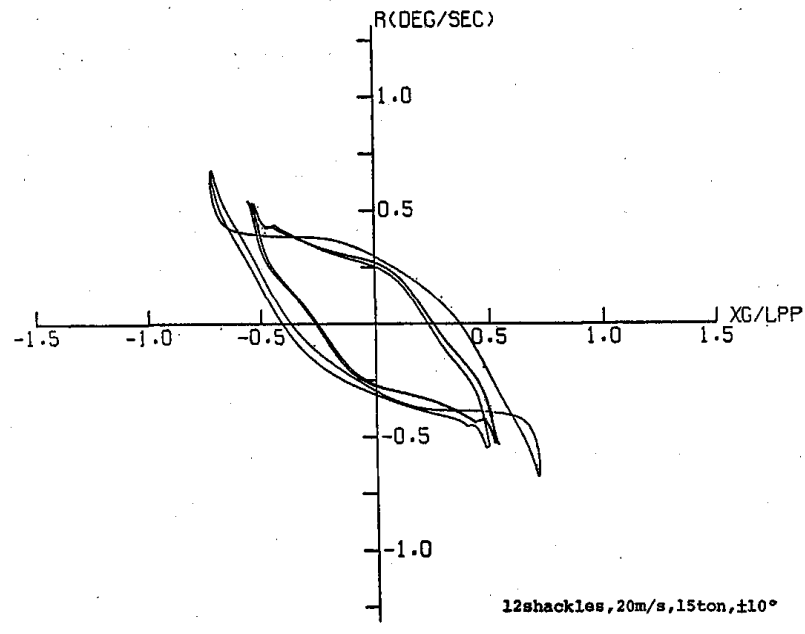

図 9 バウスラスター作動後に打ける船体重心の 横移動量と船首回頭角速度の関係

制御を開始した。

四6はシミュレーションタイム 1 時間についての振れ回り軌跡を示している。振れ回りの抑制に対するバウス ラスターの効果は作動直後から顕著に現われ，次の $1 \sim 2$ 周期目にはスラスタ一推力と風圧外力とがバランスし て定常的な振れ回り軌跡を示すよらになることがわかる。図 7 は振れ回り運動の諸要素と錨鎖張力の減衰の様子 を示し，図の最下段はバウスラスターの作動時間と推力の方向を表わしている。るた，図 8 および図 9 は重心の 横移動速度および船首回頭角速度の減衰の様子を船体の横移動量に対する位相図で表わしたもので，いずれもバ ウスラスター作動後直らに効果が現われ，定常状態に至る様子がよくわかる。

この計算例ではバウスラスターによる制御を開始する点を船体重心が最も左に振れ切った点に設定したが，こ の他に制御開始点を種々変えて計算を実施したところ，どの場合も 1 ～ 2 周期後には全く同じ結果になることが 確かめられた。したがって，振れ回り中のどの時点からバゥスラスターを使用しはじめてもその効果に変わりは ないとい光る。

3. 2 不感帯の設定

一定の船首角の範囲を不感帯として設定するとき，その範囲のとり方によって効果に差が生じることが予想さ れる。そこで, 錨鎖伸出長 12 節，風速 $20 \mathrm{~m} / \mathrm{s}$ ，バウスラスター推力 15 ton (正面風圧の0.61倍) の同一条件のも とで, 不感帯の大きさを $\pm 10^{\circ}, \pm 5^{\circ}, \pm 0^{\circ}$ に変えて計算を行い結果を比較した。表 3 は各要素についての減 衰率をとりまとめたものであるが，ここに，減衰率とは基準值に対する隇衰量を基準値に対する百分比で表わし たものである。

表 3 バウスラスター制御に拈ける不感帯設定の効果

（計算条件 錨鎖伸出長 12 節，風速 $20 \mathrm{~m} / \mathrm{s}$ ，バウスラスター推力 15 ton）

\begin{tabular}{|c|c|c|c|c|c|c|c|c|}
\hline \multirow[b]{2}{*}{$\begin{array}{l}\text { 不感帯の } \\
\text { 大きさ }\end{array}$} & \multicolumn{4}{|c|}{ 減 } & 衰 & \multicolumn{3}{|c|}{ 率 } \\
\hline & $\begin{array}{c}\text { 衝撃力 } \\
\left(T_{I}\right)\end{array}$ & $\begin{array}{c}\text { 定常張力 } \\
\left(\boldsymbol{T}_{S}\right)\end{array}$ & $\begin{array}{c}\text { 船体重心の } \\
\text { 振机振 } \\
\text { 幅 } \\
\\
\left(X_{G}\right)\end{array}$ & $\mid \begin{array}{c}\text { 最大船首角 } \\
\left(\phi_{m a x}\right)\end{array}$ & $\begin{array}{l}\text { 横移動速度 } \\
\text { 最大值 } \\
\left(V_{X \max }\right)\end{array}$ & $\begin{array}{c}\text { 船首回頭角这作 } \\
\left(R_{m a x}\right)\end{array}$ & 振れ回り周 & 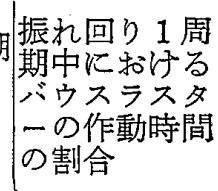 \\
\hline $\pm 10^{\circ}$ & $-31 \%$ & $-24 \%$ & $-25 \%$ & $-13 \%$ & $-24 \%$ & $-21 \%$ & $-2 \%$ & $85 \%$ \\
\hline $\pm 5^{\circ}$ & $-30 \%$ & $-25 \%$ & $-26 \%$ & $-15 \%$ & $-24 \%$ & $-26 \%$ & $-2 \%$ & $92 \%$ \\
\hline $\pm 0^{\circ}$ & $-25 \%$ & $-24 \%$ & $-27 \%$ & $-15 \%$ & $-25 \%$ & $-24 \%$ & $-2 \%$ & $100 \%$ \\
\hline
\end{tabular}

不感帯を設定する場合は設定しない場合に比べ，振れ回りの抑制効果はやや劣るが，衝撃力については逆に， 不感帯を設ける方がその緩和効果は大きい。また，振れ回り 1.周期中に和けるバウスラスターの作動時間の割合 は不感帯を設けない場合は $100 \%$ 稼動状態であるのに対して不感帯を $\pm 10^{\circ}$ に設定した場合は $85 \%$ 
る。つまり，この場合，バウスラスターは振れ回り 1 周期中に15\%の休止時間を持つことになる。

これらの点を考慮すればバウスラスターの操作に際しては，少なくとも 望ましいと思われる。そして，このよらな不感帯の設定はバゥスラスターの稼動に余裕を与光，さらに，推力方 向の切换時に护げシックラッシニの問題や実際の風の昜に晾けるこきざみな風向変動にも対処し得ることにな り，実用面に誩いてもその利点は大きいといえよう。

3. 3 バゥスラスター推力の大きさとその効果

3.3.1 振れ回り運動の抑制效果

バウスラスターの利用によってどの程度振れ回り運動が抑制され，錨鎖張力が緩和されるかを定量的に評価す るために，ここでは，錨鎖伸出長 12 節，風速 $15 \mathrm{~m} / \mathrm{s}, 20 \mathrm{~m} / \mathrm{s}, 30 \mathrm{~m} / \mathrm{s}$, 不感帯 $\pm 10^{\circ}$ の条件のもとで一連のシ ミュレーションを実施した。な拉，バウスラスターの推力は風速 $15 \mathrm{~m} / \mathrm{s}$ (正面風圧 13.8 ton）の場合は 2.5 ton 15 ton，風速 $20 \mathrm{~m} / \mathrm{s}$ (正面風生 24.6ton) の昜合は 5 ton 25 ton，風速 $30 \mathrm{~m} / \mathrm{s}$ (正面風圧 55.4 ton) の 場合は 10ton〜60ton の範囲で設定を変えた。このような推力の大きさはいずれの風速に拈いても正面風圧の

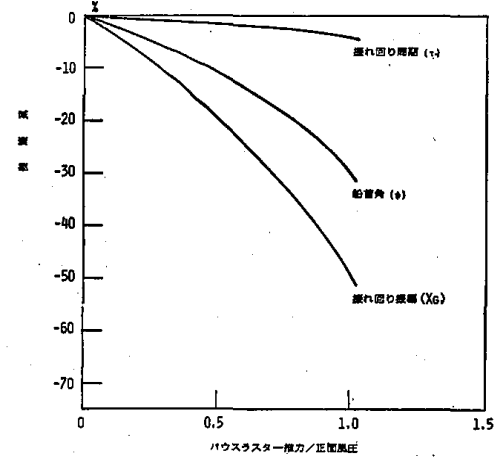

図10，振れ回り運動の抑制効果

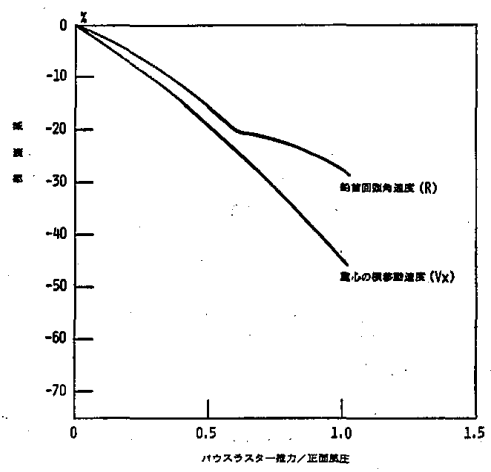

図11振孔回り運動速度の軽減 効果
$0.2 \sim 1.2$ 倍に相当する。

おのおのの風速についてバウスラス タ一推力の大きさを順次増加させて計 算を行ったところ，いずれの風速に ついてもバウスラスターの推力が正面 風圧と同等以下の範囲では振れ回り運 動はバゥスラスターの推力と風圧外力 がバランスして一定の振幅に括らつく が，バウスラスターにそれ以上の推力 を与えた場合には振れ回り運動はもは や定常的ではなくなり，“運動は不安定

となることがわかった。

図10, 図11はバウスラスター推力の増大に伴ない振れ回りに関する諸要素がどの程度減衰するかを定常的な振 れ回り状態を示す範囲内のデータについてとりまとめたものである。なお，図の縦軸は減衰率を示し，横軸はバ ウスラスターの推力を正面風圧に対する比で示している。

振れ回りに関する諸要素はバゥスラスター推力の増大に伴ない顕著な減衰傾向を示す。いま, バウスラスター に正面風圧と同じ大きさの推力を与えるとき，船首角は $30 \%$ ，振れ回り振幅は $50 \%$ 減亭し，かなり大きな振れ回 り抑制効果が認められる。また，船首回頭角速度および重心の横移動速度もそれぞれ30\%，50\%の減衰率を示し， 運動速度を減衰させる効果も著しい。しかしながら, 振れ回り周期にはそれ注どなな変化はみられない。このこ とは運動速度の減衰に伴なって船体は全体にゆっくりとした振れ回り運動を行うよらになることを意味している。

\section{3 .2 錨鎖張力の緩和効果}

錨鎖張力に関しては，バウスラスターによる制衔を行うことにより衝撃力のあらわれ方に異なった特徵がみ られるようになる。四12はその様子を錨鎖伸出長12節，風速 $20 \mathrm{~m} / \mathrm{s}$ を例に振れ回り軌跡とともに示したもので ある。図12(A)はバゥスラスターを使用しない場合，(B)はバゥスラスタ一推力 15ton (正面風圧の 0.61 倍), （C）はバゥスラスター推力 25ton（正面風圧の 1.02倍）の場合であり，不感帯はいずれる士10である。なお， 図には衝撃力之衝撃力発生時の船体姿勢を（1），（2）の番号を付して対応つけ，定常張力に関しては（3）の 番号を付して対応ら゙けている。

衝撃力は振れ回りの両端に新いて；船体が風上に切り上がり錨鎖が一旦たるえだ後，急激な船首回頭とともに 船首が風下に拈とされる過程の中で発生するが，バゥスラスターを使用しない場合はこれらの状況が注とんど同 時に重畳して作用するため衝撃力は図 12 (A) にみられるよらに振れ回りの両端で 1 回ずつ発生する。ところ が，バウスラスターを使用して船体姿勢を制御するとき，衝撃力のピークは図 $12(\mathrm{~B}) ，(\mathrm{C})$ にられるように相 続いて 2 回あらわ机るらになる。 

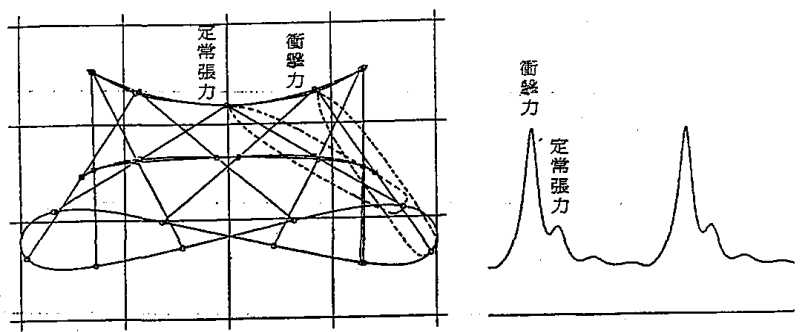

（A）バウスラスター作動なし
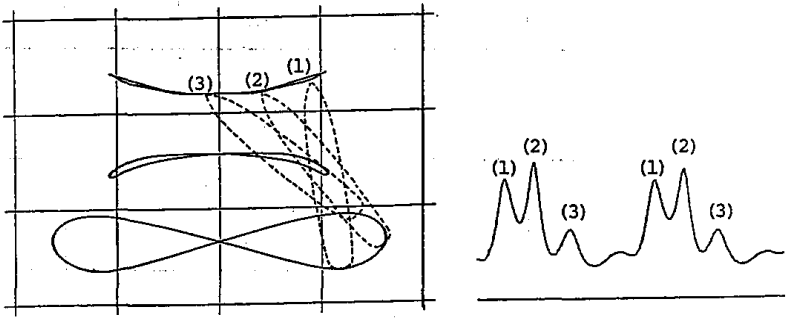

（B）バウスラスター推力 15Ton

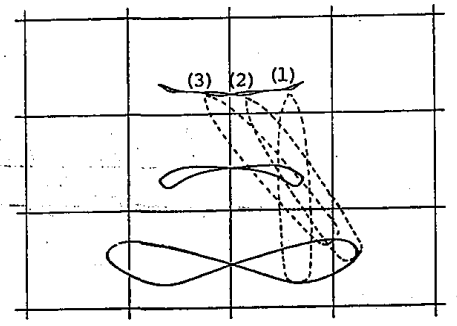

(C) バウスラスター推力 25Ton

12 shackles , $20 \mathrm{~m} / \mathrm{s}, \pm 10^{\circ}$

図12 バウスラスター制御に伴なら錨鎖張力の変動特性

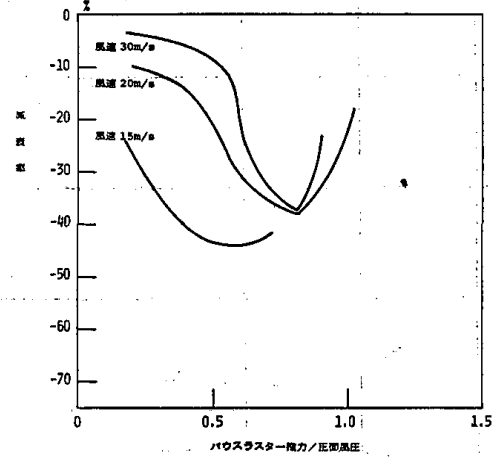

図13 衝撃力の緩和効果

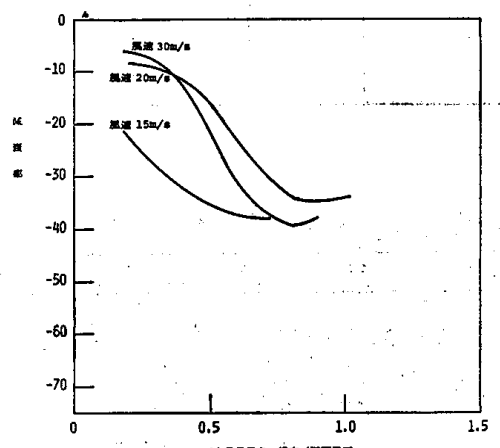

図14 定常張力の緩和効果

これはバウスラスターの姿勢制御効果と運動速度の軽減効果によって振れ回りの両端での船体運動がとくに緩 慢になるとともに船体が風に立つ状況が長く続くようになり，結果的に図中（1）の番号で示すように主として 船体の風下圧流にもとづく衝撃力と, 図中（2）の番号で示すよらに主として急激な船首回頭などの船体運動に もとづ衝撃力とが分離独立してあらわれるようになるためと推定される。

また，バゥスラスターの推力を大きくするにつれて相続く 2 回の衝撃力のらち， 1 回目の衝撃力は次第に顕著 になり，逆に 2 回目の衝撃力は減衰していく傾向がみられるが，これは，船首を風に立てる效果と運動速度を減 衰させる効果がバウスラスターの推力增大ととるにより顕著になるためと考えられる。

図13，図14はバゥスラスタ一推力の増大に伴ない錨鎖張力がどの程度減衰するかを定常的な振れ回り状態を示 す範囲内のデータについてとりまとめたものである。なお， 衝撃力については相続く 2 回のピークのらち大きい 方のピークを代表值として取り扱った。

錨鎖張力の緩和効果は風速が弱いほど顕著であるが，風速が $20 \mathrm{~m} / \mathrm{s}$ 以上の強風域では効果の程度に大きな美 はみられない。このように風速によって効果のあらわれ方に差が生じるのは錨鎖張力の持つ非線型性によるもの と思斿れる。

風速 $15 \mathrm{~m} / \mathrm{s}$ に和ける衝擎力の緩和効果は著しく，正面風圧の 0.6 倍のバウスラスター推力に特いて約 $45 \%$ の 減衰率を示す。かしながら，それ以上の推力を与えると効果はむしろ減退する。風速 $20 \mathrm{~m} / \mathrm{s} ; 30 \mathrm{~m} / \mathrm{s}$ の強風 域に括いては正面風圧の $0.4 \sim 0.5$ 倍の推力を与穴る頃から緩和効果は顕著となり，正面風圧の 0.8 倍で最も減 衰率は大きくなる。このときの減衰率はほぼ38\%であるが，やはりこれ以上の推力では逆に効果は減退する。

このように, バウスラスターに一定限度以上の大きな推力を与兄ると衝撃力の緩和効果が減退するのは，相続 いて生じる 2 回の衝撃力のうら風下圧流にもとづく衝撃力がバウスラスター推力の増加とともに顕著な増大を示 すことによるものである。

定常張力の綬和効果については, 衝撃力の場合とほぼ同様の傾向を示し, 正面風圧の 0.8 倍のバウスラスター 推力に和いて最も效果は大きく35４0\%の減衰率となる。しかしながら，定常張力の場合はバウスラスターの推 


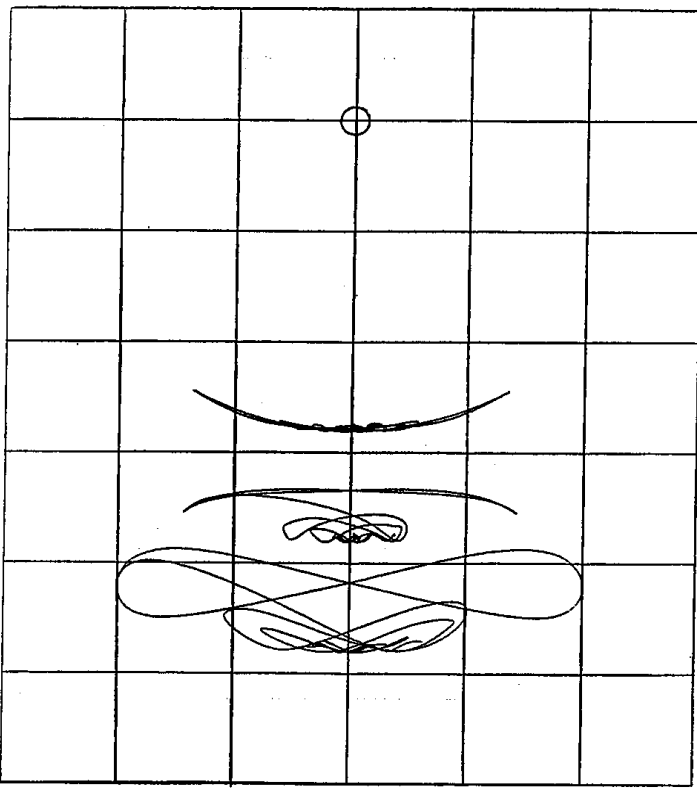

籍 8

12 shackles, $20 \mathrm{~m} / \mathrm{s}, 15$ ton, +100

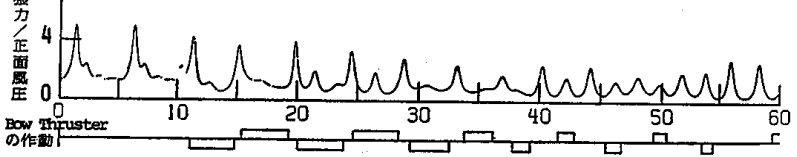

図15 バウスラスターに過大推力を与えた時の振れ

回り軌跡之錨鎖張力の変化

(シミュレーションタイム 0 タ0分)
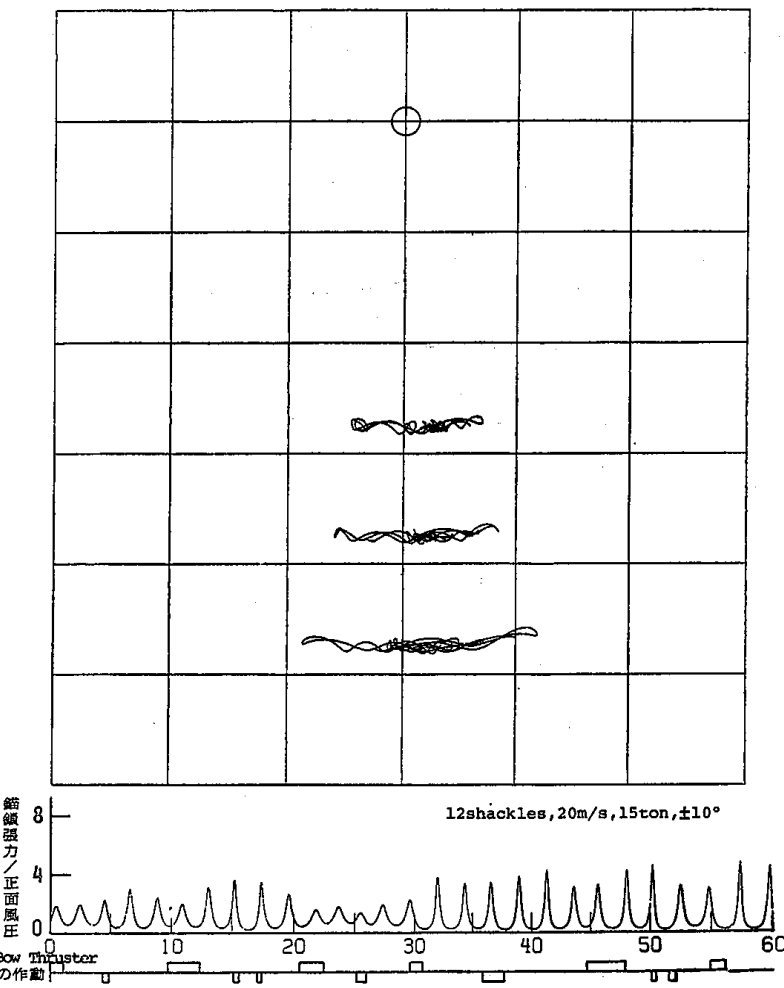

図16 バウスラスターに過大推力を与えた時の振れ 回り軌跡之錨鎖張力の変化 (シミュレーションタイム60〜120分)

力をさらに大きくしても著しい効果の減退はみられない。

3.3.3 有効なバウスラスター推力の大きさ

図15，図16はバウスラスターに正面風圧よりもさらに大きな推力を与市たときの振れ回り軌跡と錨鎖張力の変 動の様子を，鈿鎖伸出長 12 節，風速 $20 \mathrm{~m} / \mathrm{s}$ ，バウスラスター推力 30 ton (正面風圧の 1.22 倍)，不感帯 $\pm 10^{\circ} の$ 場合を例に示している。なお，図16は図15に引き続く 1 時間分のシミュレーション結果である。

この例にみられるように，バウスラスターの推力を正面風圧よりも大きくすると，もはや振れ回り運動は定常 的ではなくなり，運動振幅は急激に減衰する。そして，バウスラスター作動後 $1 \sim 2$ 周期後には船体は一旦風に 立台ほとんど静止状態に至る。このとき，錨鎖張力は極めて小さくなるが，船体はこの状態を保ち得ず，その後 は激しい前後運動と不安定な左右へのドリフトを繰り返すようになる。これとともに錨鎖張力には極めて大きな 衝撃力があらわれ，その大きさはバウスラスターを使用しない場合よりるかえって大きな值を示すことるある。

一般に単錨泊においては，船体が風に立つ状態は不安定な平衡状態であり，定常的な振れ回り運動を行ら状態 が安定な状態であるといわれている(5)。この意味からすれば図15，図16にみられるようにバウスラスターに強力 な推力を与えて強引に振れ回りを抑止しようとするより，むしろ，現状においてはある程度の振れ回りを許容し ながら錨鎖張力の緩和を計るのが現実的であるとい方らう。

したがって，錨鎖張力の緩和を目的としてバウスラスターを利用する場合，風速 $15 \mathrm{~m} / \mathrm{s}$ に拉いては正面風圧 の 0.6 倍, 風速 $20 \mathrm{~m} / \mathrm{s}$ 以上の強風域に执いて怔面風圧の 0.8 倍程度の大きさの推力が適当であるうと考学ら れ，これにより錨鎖張力は衝撃力，定常張力ともにほぼ40\%減衰させることが可能であり，同時に振れ回り振幅 も少なくとも $35 \%$ 減衰するものと予想される。

\section{4.む す び}

バゥスラスターの発生する横力と回頭モー・メンを利用して船体の横移動速度と船首回頭角速度を減衰させる ことを試み，これが振れ回りの抑制执よび錨鎖張力の緩和にどの程度効果的であるかをシミュレーションにより 評価した。本シミュレーションは風向と船首方位の間に一定以上のずれが生じたとき，そのずれを解消する方向 にバウスラスターを作動させ，できるだけ船首を風に立てるようにしようとするものであり，現状の船において 直ちに適用可能な方法である。 
振れ回り中にバウスラスターを使用する場合，このようなごく単純な制御方法によっても，振れ回りの抑制， 運動速度の軽減，錨鎖張力の緩和に対しかなりの効果を期待し得ることがわかった。また，バウスラスターの使 用に関して次に示すような指針を得た。

（1）振れ回り中のどの時点からバウスラスターを使用しはじめてもその効果には変わりはない。

（2）風向と船首方位のずれに対して過敏な制御を行らよりは，むしろ風向を中心に $10^{\circ}$ 程度の不感帯を設定 することが望ましい。

（3）現状ではある程度の振れ回りを許容しながら錨鎖張力の緩和を計るのが現実的であり，この意味に揖いて はバゥスラスター推力は子想される正面風生の 60 ～80\%程度の大きさが適当と思われる。

（4）このとき，錨鎖張力は衝擊力，定常張力ともにほぼ40\%減衰し，同時に振れ回り振幅は $35 \%$ 減衰すると推 定される。

なお，船体の姿勢制御効果が顕著になるにつれて風下王流にもとづく衝撃力は増大するが，これは振れ回りの 両端に和ける錨鎖の一時的な弛緩現象に関連する間題でもあり，これに対しては今後，制御方法の改善やバウス ラスター以外の強制力によるコントロール等を考慮する必要があると思われる。

参考文 献

（1）井上欣三，単錨泊船の振れ回り運動中に生じる錯鎖張力の緩和に関する研究一I. 錨鎖張力の大きさに影響 を及ぼす要因の分析，日本航海学会論文集，第65号，昭和56年10月

（2）辻豊治他，船体に働く風圧力に関する模型実験，船舶技術研究所報告，第 7 巻，第 5 号，昭和 45 年 7 月

（3）第 2 回操維性シンポジウムテキスト，日本造船学会，昭和45年11月

(4)、鶴田三郎，カテナリ一理論の応用限界，日本航海学会論文集，第57号，昭和52年 8 月

（5）米田唓次郎他，ブイ係留中の船のふれまわり運動の風洞実験一II，日本航海学会論文集，第30号，昭和38年 12月

\section{質 疑 応 答}

鞠谷宏士：バウスラスターの推力を強くした場合，一旦振れが収をった後，前後動 と横移動を主体とする複雑な運動にかわり，錨鎖張力が大きくなるといわれます が，そのような状態になったときのスラスターの働きはどのよらにかわるのでし よか。

井上欣三：ひとつの例として図16に和けるシミュレーションタイム45分付近での船 体姿勢は右図のような状態でありますが，このときバウスラスターの推力は右向 きに働き，船首は風に立つ方向に回頭します。そして同時に船体をさらに右方に 押すとともに前方に進出させる作用も伴ないます。このときの船体はほとんど運 動速度をむたないので強力なスラスター推力の効果は顕著にあらわれ，結果的に 船首は風に立ちますが，船体は右へさらにドリフトするとともに風上に進出し， 錨鎖は一時的に驰緩します。したがって，その後に生じる衝撃力はかえって大き な值を示すことになります。これが図16の45分から50分付近にかけてのスラスタ 一の働きと張力変動の経緯です。このように，強力なスラスター推力はほとんど 運動速度を持たない船体に対し一時的ではありますが横方向，前進方向への運動 慣性を与えます。

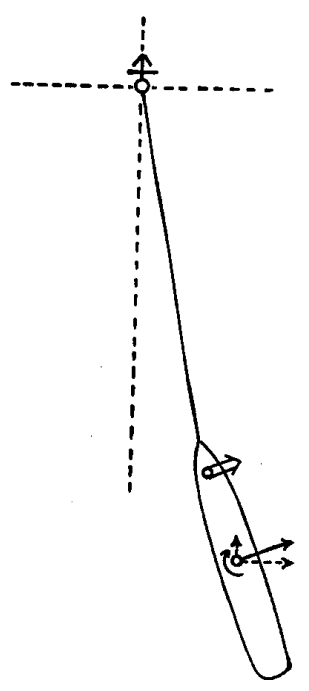

